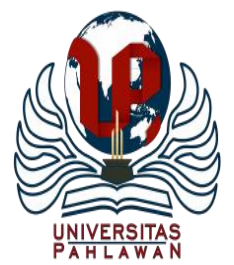

Edukatif : Jurnal Ilmu Pendidikan Volume 3 Nomor 4 Tahun 2021 Halm 1594 - 1601

EDUKATIF: JURNAL ILMU PENDIDIKAN

Research \& Learning in Education

https:/ledukatif.org/index.php/edukatif/index

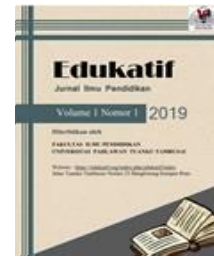

\title{
Peningkatan Hasil Belajar Menggunakan Model Pembelajaran Problem Based Learning pada Siswa Sekolah Dasar
}

\author{
Arindra Ikhwan Nur Huda ${ }^{1 凶}$, Muhammad Abduh² \\ Universitas Muhammadiyah Surakarta, Indonesia ${ }^{1,2}$ \\ E-mail : arindrahuda@gmail.com ${ }^{1}$, ma123@ums.ac.id ${ }^{2}$
}

\begin{abstract}
Abstrak
Penelitian ini bertujuan meningkatkan hasil belajar aspek kognitif pada mata pelajaran Ilmu Pengetahuan Sosial (IPS) siswa kelas V dengan menerapkan model pembelajaran Problem Based Learning (PBL). Latar belakang penelitian ini karena dalam wawancara dengan guru kelas mengungkapkan dimasa pandemi guru tersebut mengungkapkan dalam memberikan materi pembelajaran dirasa kurang maksimal karena hanya mengirimkan tugas dari buku LKS kepada siswa tanpa memberikan penjelasan. Pelaksanaan penelitian ini merupakan PTK dengan model kemmis dan Mc Taggart (Pendidikan et al., 2003). Penelitian dilakukan pada kelas V di SD Negeri 3 Pandean dengan jumlah 28 siswa. Teknik analisis data yang menggunakan analisis ketuntasan dan analisis deskripsi komparatif. Hasil penelitian menunjukkan bahwa hasil belajar siswa (KKM $\geq 75)$. Pada pra siklus diketahui presentase ketuntasan siswa sebesar 40\%. Dengan rata-rata 68,68 Kemudian pada pelaksanaan siklus I meningkat dengan presentase ketuntasan sebesar 50\% dengan rata-rata 75,43. Diteruskan pelaksanaan siklus II presentase ketuntasan siswa meningkat menjadi 85\% dengan rata-rata 82,36. Dari disimpulkan bahwa penerapan model Problem Based Learning pada SD Negeri 3 Pandean dapat meningkatkan hasil belajar siswa kelas V.
\end{abstract}

Kata Kunci : Problem Based Learning, Hasil Belajar, Kelas V.

\section{Abstract}

This study aims to improve the learning outcomes of cognitive aspects in social sciences (IPS) subjects of $5^{\text {th }}$ grade students by applying Problem Based Learning (PBL) learning models. The background of this research is because in interviews with class teachers revealed the mass pandemic teachers revealed in providing learning materials felt less than the maximum because it only sends assignments from student's worksheet books to students without giving explanations. The implementation of this research is classroom action research with kemmis model and Mc Taggart (Pendidikan et al., 2003). The research was conducted in $5^{\text {th }}$ grades th SD Negeri 3 Pandean with a total of 28 students. Analysis techniques that use completion analysis and comparative description analysis. The results showed that the student's learning outcomes (Minimum Completeness Criteria $\geq 75$ ). In pre-cycle, the percentage of students' completion is known to be $40 \%$. With an average of 68.68 Then in the implementation of cycle I increased with a percentage of completion of 50\% with an average of 75.43. Continued implementation of cycle II percentage of student completion increased to 85\% with an average of 82.36. From the conclusion that the application of Problem Based Learning model at Pandean elementary school can improve the learning outcomes of $5^{\text {th }}$ grades tudents.

Keywords: Problem Based Learning, Learning Outcomes, $5^{\text {th }}$ grades

Copyright (c) 2021 Arindra Ikhwan Nur H, Muhammad Abduh

$\triangle$ Corresponding author

Email : arindrahuda@gmail.com

DOI : https://doi.org/10.31004/edukatif.v3i4.629

ISSN 2656-8063 (Media Cetak)

ISSN 2656-8071 (Media Online)

Edukatif : Jurnal Ilmu Pendidikan Vol 3 No 4 Tahun 2021 p-ISSN 2656-8063 e-ISSN 2656-8071 
1595 Peningkatan Hasil Belajar Menggunakan Model Pembelajaran Problem Based Learning pada Siswa Sekolah Dasar - Arindra Ikhwan Nur H, Muhammad Abduh

DOI: https://doi.org/10.31004/edukatif.v3i4.629

\section{PENDAHULUAN}

Lampiran Permendikbud No 21 Tahun 2016 tentang standar isi, menyatakan muatan pembelajaran Ilmu Pengetahuan Sosial adalah bagian salah satu muatan yang di sampaikan di Sekolah Dasar (SD) dari kelas IVVI. Muatan pembelajaran IPS disusun oleh Kemendikbud dengan tujuan mengembangkan kompetensi belajar siswa secara berpikir positif seperti IPS, jadi diantaranya: mengarahkan perilaku sosial dan budaya yang mencerminkan jati diri bangsa Indonesia. Kemudian mendalami konsep ruang, waktu, dan kritis terhadap aktivitas dinamika manusia dalam kehidupan sosial, budaya, serta ekonomi.

Kurikulum 2013 dikembangkan berdasarkan budaya bangsa Indonesia yang beragam, Selain itu kurikulum 2013 mengembangkan pengalaman belajar yang memberikan kesempatan luas bagi siswa untuk menguasai kompetensi yang diperlukan bagi kehidupan di masa kini dan masa depan, dan pada waktu yang bersamaan tetap mengembangkan kemampuan mereka sebagai pewaris budaya bangsa dan orang yang peduli terhadap permasalahan masyarakat dan bangsa masa kini dalam (Anisa Astra, 2018).

Pada kurikulum 2013 terdapat salah satu muatan pembelajaran yaitu Ilmu Pengetahuan Sosial (IPS). Menurut Susanto dalam (Hermanto dkk, 2019) Hakikat IPS merupakan konsep pengembangan pemikiran yang berdasarkan ilmu realita tentang kondisi sosial yang ada di lingkungan siswa, sehingga dengan memberikan pendidikan IPS diharapkan mampu melahirkan warga negara yang baik dan bertanggung jawab terhadap bangsa. Selanjutnya pendapat lain mengenai IPS kemudian pendapat berbeda diungkapkan (Supardi et al., 2021) mata pelajaran IPS disekolah dasar merupakan program pengajaran yang bertujuan untuk mengembangkan potensi murid agar peka terhadap masalah sosial yang terjadi dimasyarakat, memilki sikap mental positif terhadap perbaikan segala ketimpangan yang terjadi, dan terampil mengatasi setiap masalah yang terjadi sehari-hari baik yang menimpa dirinya sendiri maupun yang menimpa masyarakat. Tujuan pembelajaran IPS secara umum menurut Fenton dalam (Henny Endayani, 2017) diungkapkan untuk mempersiapkan anak agar menjadi warga negara yang baik, mengajar anak agar mempunyai kemampuan berpikir dalam memecahkan permasalahan dan dapat melanjutkan kebudayaan bangsa.

Hasil observasi dan wawancara yang dilakukan di SD Negeri 3 Pandean Kabupaten Boyolali di kelas V pada muatan pembelajaran IPS masih terdapat beberapa kendala saat penerapan pembelajaran, guru mengungkapkan kendala tersebut diantaranya : (1) Ungkapan guru menyadari masalah kurang maksimalnya dalam penguasaan ICT, metode TPACK serta menerapkan keterampilan abad 21 sehingga dalam kegiatan pembelajaran sehingga masih belum adanya pengunaan media berbasis ICT di sekolah, (2) Kemudian, saat mengikuti pembelajaran siswa di dalam kelas cenderung pasif karena guru lebih dominan menjelasksan dan siswa selalu mendengarkan saja, (3) Kegiatan pembelajaran di massa pandemi guru lebih dominan untuk memberikan arahan mengerjakan modul dan LKS pada buku yang dibagikan, (4) Hasil belajar siswa saat ini masih banyak yang mendapat nilai di bawah KKM, dari 28 siswa-siswi hanya 11 siswa yang mencapai KKM, sedangkan 60\% sisanya masih belum mencapai KKM. sehingga beberapa hal tersebut mengakibatkan menurunnya hasil belajar siswa kegiatan pelaksanaan pembelajaran tersebut membuat dampak terhadap siswasiswa kelas V diantaranya yang dialami oleh siswa adalah siswa menjadi kurang bersemangat dalam mengikuti pembelajaran karena monoton kemudian kurangnya siswa dan cenderung pasif dalam pembelajaran.

Dari hasil wawancara diatas maka peneliti bersama guru kelas harus mencari solusi dalam mengatasi permasalahan pembelajaran tersebut. Hingga dipilihnya model pembelajaran Problem Based Learning PBL seperti yang diungkapkan (Setyowati \& Fimansyah, 2018) bahwa penelitian dalam melaksanakan pembelajaran IPS guru sebaiknya menggunakan model pembelajaran Problem Based Learning karena yang terbukti efektif terhadap kompetensi sikap, pengetahuan dan keterampilan siswa dengan menyesuaikan materi yang tepat terkait permasalahan sosial. kemudian apabila guru menginginkan siswa dapat mencapai ketuntasan pada kompetensi sikap maupun pengetahuan sebaiknya guru menggunakan model Problem Based 
1596 Peningkatan Hasil Belajar Menggunakan Model Pembelajaran Problem Based Learning pada Siswa Sekolah Dasar - Arindra Ikhwan Nur H, Muhammad Abduh

DOI: https://doi.org/10.31004/edukatif.v3i4.629

Learning. Karena dapat melatih siswa tidak hanya belajar satu arah dengan guru saja, namun siswa dapat belajar antar sesama temannya model pembelajaran berbasis masalah atau Problem Based Learning merupakan salah satu model pembelajaran tipe kooperatif. Menurut Rusman pada (Dirgatama dkk, 2016) pembelajaran berbasis masalah merupakan penggunaan berbagai macam kecerdasan yang diperlukan untuk melakukan konfrontasi terhadap tantangan dunia nyata, kemampuan untuk menghadapi segala sesuatu yang baru dan kompleksitas yang ada. Kemudian pendapat berbeda tentang PBL diungkapkan Shoimin pada (Ulandari dkk, 2020) mengungkapkan pengajaran yang bercirikan adanya permasalahan nyata sebagai konteks untuk para peserta didik belajar berpikir kritis dan keterampilan memecahkan masalah serta memperoleh hasil belajar pengetahuan. Selanjutnya penelitian dengan menggunakan model PBL diungkapkan oleh (Khotimah, 2019) mengungkapkan pengaruh model PBL terhadap hasil belajar siswa yang memperoleh hasil perhitungan nilai rata-rata posttest dari masing masing kelas eksperimen 80,00 sedangkan kelas kontrol 69,39. Berdasarkan data tersebut menunjukkan adanya perbedaan dari kedua kelompok, yaitu (1) nilai rata rata kelas eksperimen diatas KKM 75, sedangkan kelas kontrol dibawah KKM.(2) kelas eksperimen memperoleh nilai lebih tinggi dari kelas kontrol. Dari hasil penelitian dapat disimpulkan dengan menerapkan model PBL mampu meningkatkan hasil belajar siswa. Sependapat dengan penelitian tersebut juga diungkapkan oleh (Siti Sukaptiyah, 2015) mengungkapkan hasil penelitian tentang peningkatan hasil belajar yang memperoleh hasil belajar siswa dari siklus I ke siklus II mengalami peningkatan, yaitu dari 8 siswa $(72,7 \%)$ yang mendapat nilai tuntas menjadi 11 siswa (100\%). Terjadi peningkatan sebanyak 3 siswa $(27,3 \%)$ dan nilai rata-rata kelas dari 77,8 menjadi 83,5 meningkat sebesar 5,7.

Hasil belajar erat kaitannya dengan proses memperoleh pengetahuan. Dimyati \& Mudjiono pada (Afnan et al., 2021) mengungkapkan hasil belajar merupakan hasil dari suatu interaksi tindakan belajar dan tindakan mengajar. Sehingga perlu adanya upaya perbaikan pembelajaran yang tepat untuk meningkatkan hasil belajar siswa. Solusi untuk meningkatkan masalah tersebut yaitu dengan menggunakan model pembelajaran yang inovatif. Model pembelajaran Problem Based Learning (PBL) adalah model pembelajaran yang didalam proses pembelajaran menggunakan masalah, dalam mencapai tujuan penelitian yang akan dibahas oleh peneliti. Maka disusun hipotesis tindakan pada penelitian ini adalah : 1) mendeskripsikan bagaimana langkahlangkah penerapan model pembelajaran Problem Based Learning dapat meningkatkan hasil belajar siswa kelas V SDN 03 Pandean Kabupaten Boyolali. 2) meningkatkan hasil belajar pada pembelajaran IPS dengan menggunakan model pembelajaran Problem Based Learning siswa kelas V SDN 03 Pandean Kabupaten Boyolali.

\section{METODE PENELITIAN}

Peneliti dalam melaksanakan penelitian termasuk jenis penelitian tindakan kelas. Menurut ( Linggayani Sinulingga, 2020) Pengertian Penelitian Tindakan Kelas (PTK) adalah penelitian praktis yang dimaksudkan untuk memperbaiki pembelajaran di kelas. Penelitian tindakan kelas merupakan strategi terstruktur berupa rencana sistematis yang terdokumentasi sehingga dapat membantu guru untuk terus berinovasi terhadap segala permasalahan di kelas ungkap Ameliasari (Daswita, 2021). langkah-langkah menerapkan model PBL diungkapkan oleh hosnan dalam (Dirgatama dkk , 2016) 1) Orientasi siswa pada masalah 2) Mengorganisasikan siswa untuk belajar 3) Membimbing penyelidikan individual dan kelompok 4) Mengembangkan dan menyajikan hasil karya 5) Menganalisis dan mengevaluasi proses pemecahan masalah. Langkah tersebut merupakan dasar dalam menerapkan model PBL pada setiap pelaksanaan pembelajaran. Penelitian ini dilakukan dengan beberapa siklus, serta dengan menggunakan model spiral sesuai dengan yang dikemukakan oleh Kemmis dan Targat dalam (Hendawati and Kurniati, 2017) yang terdiri dari perencanaan, observasi \& tindakan serta refleksi. Prosedur pada setiap siklus saling berkesinambungan. 


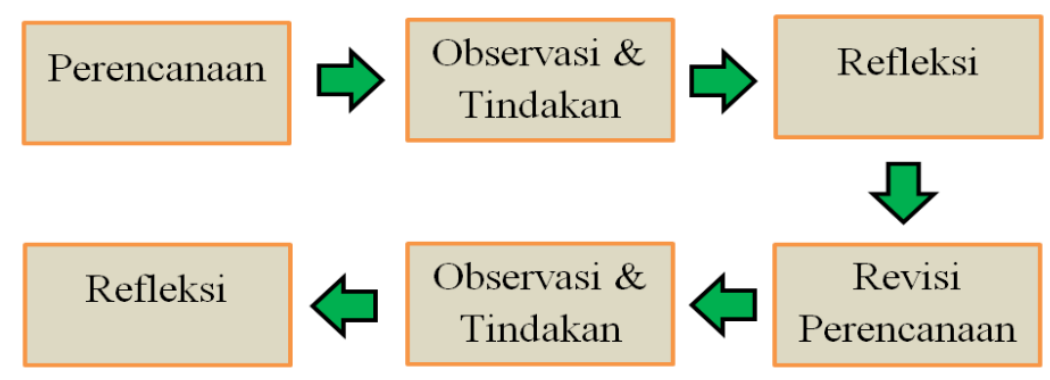

Bagan 1. Model Spiral Oleh Kemmis dan Targgat

Penelitian dilaksanakan di SD Negeri 3 Pandean semester 2 tahun ajaran 2020 / 2021. SD Negeri 3 Pandean merupakan SD yang terletak di dusun Pandean, Kecamatan Ngemplak, Kabupaten Boyolali. subjek penelitian ini adalah siswa kelas 5 SD Negeri 3 Pandean yang berjumlah 28 siswa. Pelaksanaan penelitian ini berkolaborasi dengan guru kelas 5 SD Negeri 3 Pandean yaitu Ibu Sukemi, S.Pd. pengumpulan data menggunakan teknik tes.Teknik tes yang digunakan berupa rubrik penilaian untuk mengukur tingkat keterampilan berpikir kritis siswa. Indikator penilaian yang digunakan telah disesuaikan dengan materi serta karakteristik siswa. Sistem penilaian yang digunakan pada rubrik penilaian ini ialah setiap 1 item soal mendapat skor maksimal 4 poin. Adapun skor maksimal total rubrik ialah 100 poin. Rubrik pada penelitian ini telah dilakukan uji validitas menggunakan SPSS versi 23. Sedangkan untuk teknik non tes menggunakan lembar observasi guru dan siswa. Kegiatan non tes tersebut berupa lembar observasi pembelajaran IPS dengan menggunakan prosedur model pembelajaran Problem Based Learning. Pengisisan lembar observasi tersebut dilakukan saat pembelajaran dimulai hingga di akhir.

Teknik analisis data yang digunakan pada penelitian ini merupakan teknik kuantitatif dan teknik komparatif. Pada indikator yang sudah ditetapkan peneliti melakukan perbandingan ketika tindakan Pra siklus, siklus I dan, siklus II. Pada penelitian ini ditetapkan untuk keberhasilan ditandai dengan adanya peningkatan keterampilan berpikir kritis siswa menggunakan model pembelajaran Problem Based Learning kemudian setelah diterapkan model pembelajaran Problem Based Learning pada hasil belajar siswa meningkat apabila rata-rata kelas mencapai lebih dari nilai 80 serta presentase siswa mencapai KKM lebih dari $75 \%$.

\section{HASIL DAN PEMBAHASAN}

Pelaksanaan penelitian pada SD Negeri 3 Pandean dilaksanakan sebanyak 2 siklus. Pada setiap siklus dilakukan 2 kali pertemuan. Setiap 1 kali pertemuan menggunakan alokasi waktu 3 X 35 menit pembelajaran. Selanjutnya merupakan hasil perbandingan penelitian hasil belajar siswa pada muatan pembelajaran IPS menggunakan model pembelajaran Problem Based Learning kelas 5. Hasil belajar pada pra siklus menunjukkan bahwa hasil belajar siswa masih rendah. Hasil tersebut menunjukan siswa yang mencapai nilai KKM hanya 11 orang dan siswa yang memperoleh nilai dibawah KKM sebanyak 17 siswa. Sehingga hal tersebut dibutuhkan model lain yang diharapkan dapat meningkatkan hasil belajar siswa. Selanjutya sebelum melaksanakan pada siklus 1 sesuai dengan rencana pembelajaran yang sudah disusun dengan model PBL: dimulai dengan pemberian materi, dilanjutkan dengan mengarahkan siswa pada masalah, membagi siswa menjadi beberapa kelompok dan dan siswa menyelesaikan LKPD yang telah disusun dan dan mengerjakan lembar evaluasi hingga membuat kesimpulan serta tindak lanjut hingga penutup. Dibawah ini tabel hasil data setelah melaksanakan siklus I dan II: 
1598 Peningkatan Hasil Belajar Menggunakan Model Pembelajaran Problem Based Learning pada Siswa Sekolah Dasar - Arindra Ikhwan Nur H, Muhammad Abduh

DOI: https://doi.org/10.31004/edukatif.v3i4.629

Tabel 1. Perbandingan Hasil Belajar IPS siswa

\begin{tabular}{lcccccc}
\hline \multirow{2}{*}{ Kriteria } & \multicolumn{2}{c}{ Pra Siklus } & \multicolumn{2}{c}{ Siklus I } & \multicolumn{2}{c}{ Siklus II } \\
\cline { 2 - 8 } & Jumlah & \% & Jumlah & \% & Jumlah & \% \\
\hline Tuntas & 11 & $40 \%$ & 14 & $50 \%$ & 24 & $85 \%$ \\
\hline Tidak Tuntas & 17 & $60 \%$ & 14 & $50 \%$ & 4 & $15 \%$ \\
\hline Jumlah & 28 & $100 \%$ & 28 & $100 \%$ & 28 & $100 \%$ \\
\hline Skor Maksimal & \multicolumn{2}{c}{86} & \multicolumn{2}{c}{85} & \multicolumn{2}{c}{91} \\
\hline Skor Minimal & \multicolumn{2}{c}{48} & \multicolumn{2}{c}{65} & 71 \\
\hline Rata-Rata & 68,68 & 75,43 & 82,36 \\
\hline
\end{tabular}

Dari tabel perbandingan hasil belajar diketahui merupakan hasil pelaksanaan penelitian siklus I dan II. Hasil belajar pada siklus I diperoleh hasil nilai siswa meningkat pada ketuntasan KKM nya dibanding pada pra siklus. kemudian siswa yang mendapat nilai $\geq 75$ sebanyak 14 siswa. Ketuntasan klasikal pada siklus I bila dibandingakan dengan indikator kinerja yang telah ditetapkan yaitu ketuntasan belajar siswa secara klasikal 75\% dan siswa telah memenuhi KKM sebanyak 14 siswa, maka analisis data pada siklus I ini belum tuntas karena ketuntasan klasikal masih di bawah indikator kinerja yaitu hanya 50\% di bawah ketuntasan klasikal yang ditetapkan dalam penelitian adalah 75\%. Pada tabel I juga dapat dilihat nilai tertinggi siswa yaitu 85 dan nilai terendah 65 dengan rata-rata nilai 75,43. Karena belum mencapai indikator keberhasilan maka dari itu dilakukan tindakan siklus II.

Selanjutnya setelah siklus II. Diperoleh hasil bahwa jika nilai siswa dibandingkan dengan KKM dapat disimpulkan bahwa terdapat 21 siswa yang nilainya $\geq 75$. Siswa yang belum memenuhi KKM yaitu 4 siswa, maka analisis data pada siklus II sudah tuntas karena telah mencapai indikator kinerja yang ditetapkan yaitu sebesar $85 \%$ di atas ketuntasan klasikal yang ditetapkan dalam penelitian yaitu $75 \%$. Nilai tertinggi pada siklus II yaitu 91 dan nilai terendah pada siklus II 71 dengan rata-rata nilai adalah 82,36. Berikut sajian diagram hasil belajar siswa dalam setiap siklusnya:

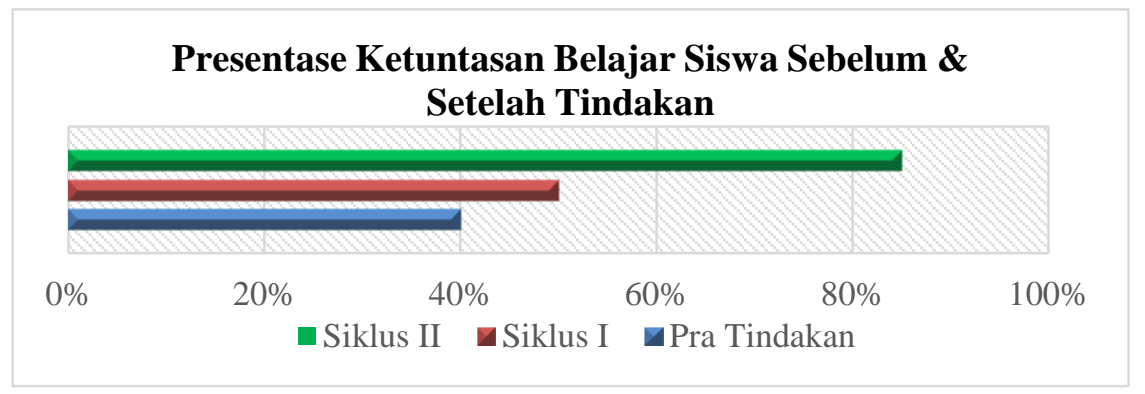

Gambar 1. Diagram Presentase Ketuntasan Hasil Belajar Siswa

Berdasarkan hasil analisis pembelajaran siklus I dan II menunjukkan hasil belajar siswa menjadi lebih baik dengan menggunakan model pembelajaran Problem Based Learning. Sejalan dengan pendapat tersebut Mawardi pada (Aini Relmasira, 2018) mengungkapkan model pembelajaran tersebut dapat mencapai tujuan pembelajaran. Diketahui pembelajaran yang sudah terlaksana mendapati nilai pra siklus yang tidak disertai dengan pemberian treatment. Hal ini dibuktikan dengan meningkatnya hasil belajar pada siklus I yang memperoleh hasil siswa yang mencapai nilai $\geq 75$ sebesar 14 siswa dengan presentase $50 \%$, Akan tetapi peningkatan yang terjadi pada siklus I belum memenuhi target indikator kinerja yang telah ditetapkan yaitu 75\% dari 28 siswa, maka dilanjutkan pada siklus II. Perbaikan yang telah dilaksanakan pada siklus I sesuai 
1599 Peningkatan Hasil Belajar Menggunakan Model Pembelajaran Problem Based Learning pada Siswa Sekolah Dasar - Arindra Ikhwan Nur H, Muhammad Abduh

DOI: https://doi.org/10.31004/edukatif.v3i4.629

dengan rencana berdasarkan refleksi yang dikalakukan didapatkan hasil siswa yang mendapat nilai $\geq 75$ sebanyak 24 siswa dengan presentase $85 \%$ serta siswa yang belum mencapai KKM sebanyak 4 siswa dengan presentase $15 \%$. Hal ini sejalan dengan penelitian kemudian nilai yang diperoleh siswa diketahui nilai maksimal siswa 91 dan nilai minimalnya 71. Kemudian dari pelaksanaan penelitian sejalan dengan (Pramudya dkk, 2019) mengungkapkan pembelajaran menggunakan Problem Based Learning dalam meningkatkan hasil hasil belajar memperoleh hasil belajar siswa dengan kondisi awal (pra siklus) 62,17 dengan jumlah siswa yang tuntas sebanyak 13 siswa $(38,23 \%)$ mengalami peningkatan pada siklus I dengan rata-rata nilai 78,39 dengan jumlah siswa tuntas sebanyak 23 siswa $(67,64 \%)$ dan pada siklus II rata-rata nilai siswa adalah 83,29 dengan jumlah siswa tuntas sebanyak 28 siswa $(82,36 \%)$. Kemudian pendapat lain disampaikan oleh (Ayuningsih dkk, 2019) dalam meningkatkan hasil belajar dan berpikir kritis, pada hasil belajar diketahui peningkatan terjadi ditunjukan dariketuntasan hasil belajar siswapada tahap siklus I sebanyak 11 siswa dengan persentase 40,7 dan semakin meningkat pada siklus II menjadi 19 siswa dengan persentase 70,3. Sejalan dengan penelitian yang telah dilaksanakan diketahui bahwa model pembelajaran Problem Based Learning mampu meningkatkan hasil belajar siswa.

Selanjutnya pada penelitian ini masih terdapat keterbatasan dalam penelitian, diantaranya 1) Dimasa pandemi ini pembelajaran secara luring masih terbatas dalam setiap pertemuannya, sehingga perlunya penyampaian materi dibuat secara intinya saja, 2) Pada pelaksanaan pengerjaan LKPD siswa menjadi kesulitan mengerjakan karena dalam pelaksanaanya siswa perlu menjaga jarak sehingga tidak dapat berjalan maksimal. 3) Keterbatasan dalam memahami karakteristik siswa sebagai upaya dalam menyampaikan materi pembelajaran. Penelitian yang sudah terlaksana juga memberikan dampak pada siswa dalam melaksanakan pembelajaran dengan menggunakan model PBL, siswa menjadi lebih antusias dan aktif mengikuti setiap proses pembelajaran, lebih berani di dalam menyampaikan gagasan dan melakukan kegiatan tanya jawab bersama guru, dengan penerapan model Problem Based Learning. Pembelajaran yang berlangsung menjadi lebih menarik dan bermakna bagi siswa, proses pembelajaran tidak hanya terpusat pada guru melainkan siswa juga ikut terlibat dalam proses pembelajarannya.

\section{KESIMPULAN}

Berdasarkan hasil penelitian yang sudah dilaksanakan dapat disimpulkan bahwa : 1) Model pembelajaran Problem Based Learning dengan langkah-langkah :mengarahkan pada masalah, mengarahkan siswa pada materi, membimbing penyelidikan berkelompok, Mengarahkan siswa dalam menyajikan karya, menganalisis serta evaluasi proses pemecahan masalah dapat meningkatkan keterampilan berpikir kritis siswa pada muatan pembelajaran IPS kelas 5 SD Negeri 3 Pandean, kemudian 2) hasil penelitian diketahui bahwa adanya peningkatan terhadap hasil belajar siswa, hal tersebut dibuktikan dengan hasil penelitian menunjukkan bahwa hasil belajar siswa (KKM $\geq 75)$. Pada pra siklus diketahui presentase ketuntasan siswa sebesar $40 \%$. Dengan rata-rata 68,68 kemudian pada pelaksanaan siklus I meningkat dengan presentase ketuntasan sebesar $50 \%$ dengan rata-rata 75,43. Diteruskan pelaksanaan siklus II presentase ketuntasan siswa meningkat menjadi 85\% dengan rata-rata 82,36. Demikian dapat disimpulkan bahwa model pembelajaran Problem Based Learning dapat meningkatkan hasil belajar siswa kelas 5 pada muatan pembelajaran IPS semester 2 Tahun ajaran 2020/2021.

\section{UCAPAN TERIMAKASIH}

Penulis dalam menyusun penelitian ini mengucapkan puji syukur kepada Allah SWT atas limpahan rahmat dan hidayah dalam menyusun penelitian ini. Peneliti mengucapkan kepada kedua orang tua, yang telah memberikan dukungan secara moral dan materiil. Terimakasih kepada Bapak Muhammad Abduh selaku 
1600 Peningkatan Hasil Belajar Menggunakan Model Pembelajaran Problem Based Learning pada Siswa Sekolah Dasar - Arindra Ikhwan Nur H, Muhammad Abduh

DOI: https://doi.org/10.31004/edukatif.v3i4.629

Dosen pembimbing Pendidikan Profesi Guru Universitas Muhammadiyah Surakarta dan guru pamong, serta teman-teman PPL dan Kepala sekolah, guru dan staf SD Negeri 3 Pandean yang telah memberikan bimbingan dan arahannya. Semoga penelitian yang disusun dapat bermanfaat bagi semua. Serta pihak yang telah memberikan dukungan dalam peneliti.

\section{DAFTAR PUSTAKA}

Afnan, D., Astuti, P., Tyas, A., Hardini, A., Kristen, U., Wacana, S., Belajar, H., Kalor, P., \& Esa, Y. M. (2021). UPAYA MENINGKATKAN HASIL BELAJAR DENGAN MODEL DISCOVERY LEARNING BERBANTUAN POWERPOINT SECARA DARINGKELAS V SD. 9(2), 96-100.

Aini, Q., \& Relmasira, S. C. (2018). Penerapan Pembelajaran Tematik Integratif Berbasis Kontekstual untuk Meningkatkan Keaktifan dan Hasil Belajar Siswa Kelas 1 SD. Sekolah Dasar: Kajian Teori Dan Praktik Pendidikan, 27(2), 124-132. https://doi.org/10.17977/um009v27i22018p124

Anisa Astra, J., Mardiyana, \& Triyanto. (2018). Pendekatan dan Penilaian Pembelajaran pada Kurikulum 2013 Revisi 2017 yang Mendukung Peningkatan Kemampuan Koneksi Matematis Siswa. Jurnal Elektronik Pembelajaran Matematika, 5(3), 286-299.

Ayuningsih, D., Kristin, F., \& Anugraheni, I. (2019). Penerapan Model Pembelajaran Problem Based Learning (Pbl) Untuk Meningkatkan Hasil Belajar Dan Berpikir Kritis Matematika. Jurnal Cakrawala Pendas, 5(2), 94-99. https://doi.org/10.31949/jcp.v5i2.1351

Dirgatama, C. H. A., Th, D. S., \& Ninghardjanti, P. (2016). Penerapan Model Pembelajaran Problem Based Learning Dengan Mengimplementasi Program Microsoft Excel Untuk Meningkatkan Keaktifan Dan Hasil Belajar Mata Pelajaran Administrasi Kepegawaian Di Smk Negeri 1 Surakarta. Jurnal Informasi Dan Komunikasi Administrasi Perkantoran, 1(1), 36-53. https://jurnal.uns.ac.id/JIKAP/article/view/19138

Hendawati, Y., \& Kurniati, C. (2017). Penerapan Metode Eksperimen Terhadap Pemahaman Konsep Siswa Kelas V Pada Materi Gaya Dan Pemanfatannya. Metodik Didaktik, 13(1). https://doi.org/10.17509/md.v13i1.7689

Hermanto, Japar, M., \& Utomo, E. (2019). Implementasi Pembelajaran Ilmu Pengetahuan Sosial (IPS) dalam Membentuk Karakter Siswa (The Implementation of Social Science Learning in Building Students' Characters. Jurnal Pendidikan Dasar Islam, 6(1), 1-6.

In, M., Mipa, C. X., \& Negeri, S. M. A. (2021). MENARA Ilmu Vol. XV No.01 April 2021. XV(01), 18-31.

Khotimah, D. K. dan sulthoni. (2019). Pengaruh Model Problem Based Learning Terhadap Hasil Belajar Pkn Siswa. Jurnal Kajian Teknologi Pendidikan, 2(2), 158-165.

Meningkatkan, U., Mengidentifikasi, K., Dari, I., Eksplanasi, T., Pemberian, D., Yang, T., Dengan, D., \& Dikelas, P. (2020). Jurnal Pendidikan Pengajaran. 1(3), 217-238.

Pendidikan, J., Sekolah, G., Alat, P., Iv, K., Negeri, S. D., \& Tinggi, K. (2003). Jurnal PGSD. 11(2), 128 134.

Pramudya, E., Kristin, F., \& Anugraheni, I. (2019). Peningkatan Keaktifan Dan Hasil Belajar Ipa Pada Pembelajaran Tematik Menggunakan Pbl. NATURALISTIC : Jurnal Kajian Penelitian Pendidikan Dan Pembelajaran, 3(2), 320-329. https://doi.org/10.35568/naturalistic.v3i2.391

Setyowati, R., \& Fimansyah, W. (2018). Upaya Peningkatan Citra Pembelajaran IPS Bermakna di Indonesia. Jurnal PIPSI (Jurnal Pendidikan IPS Indonesia), 3(1), 14. https://doi.org/10.26737/jpipsi.v3i1.544

Siti Sukaptiyah. (2015). Peningkatan Hasil Belajar PKn M elalui Model. Jurnal Pendidikan Guru Sekolah Dasar, 15(7), 114-121.

Supardi, R., Khaedar, M., \& Alam, S. (2021). Peningkatan Hasil Belajar Ips Melalui Strategi Pembelajaran 
1601 Peningkatan Hasil Belajar Menggunakan Model Pembelajaran Problem Based Learning pada Siswa Sekolah Dasar - Arindra Ikhwan Nur H, Muhammad Abduh

DOI: https://doi.org/10.31004/edukatif.v3i4.629

Bermain Jawaban Murid Di Kelas V Sd Inpres Bangkala Iii Kecamatan .... ... (Jurnal Kajian Pendidikan ..., 6, 58-68. https://journal.unismuh.ac.id/index.php/jkpd/article/view/4816

Ulandari, W., Perdiansyah, F., \& Zamroni, M. (2020). Peningkatan Berpikir Kritis Melalui Metode Problem Based Learning Siswa Kelas Iv Sdn Pinang 6 Tangerang. Indonesian Journal of Elementary Education (IJOEE), 1(2), 42-51. https://doi.org/10.31000/ijoee.v1i2.2930

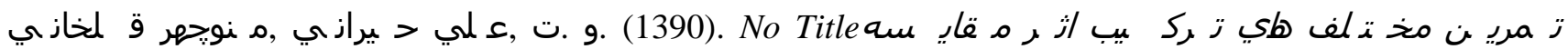

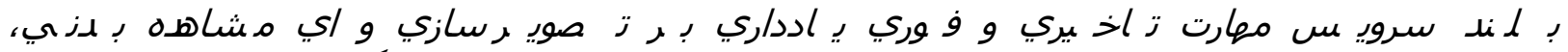

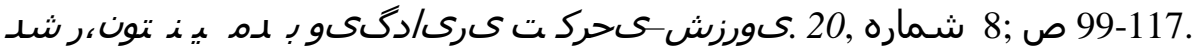

